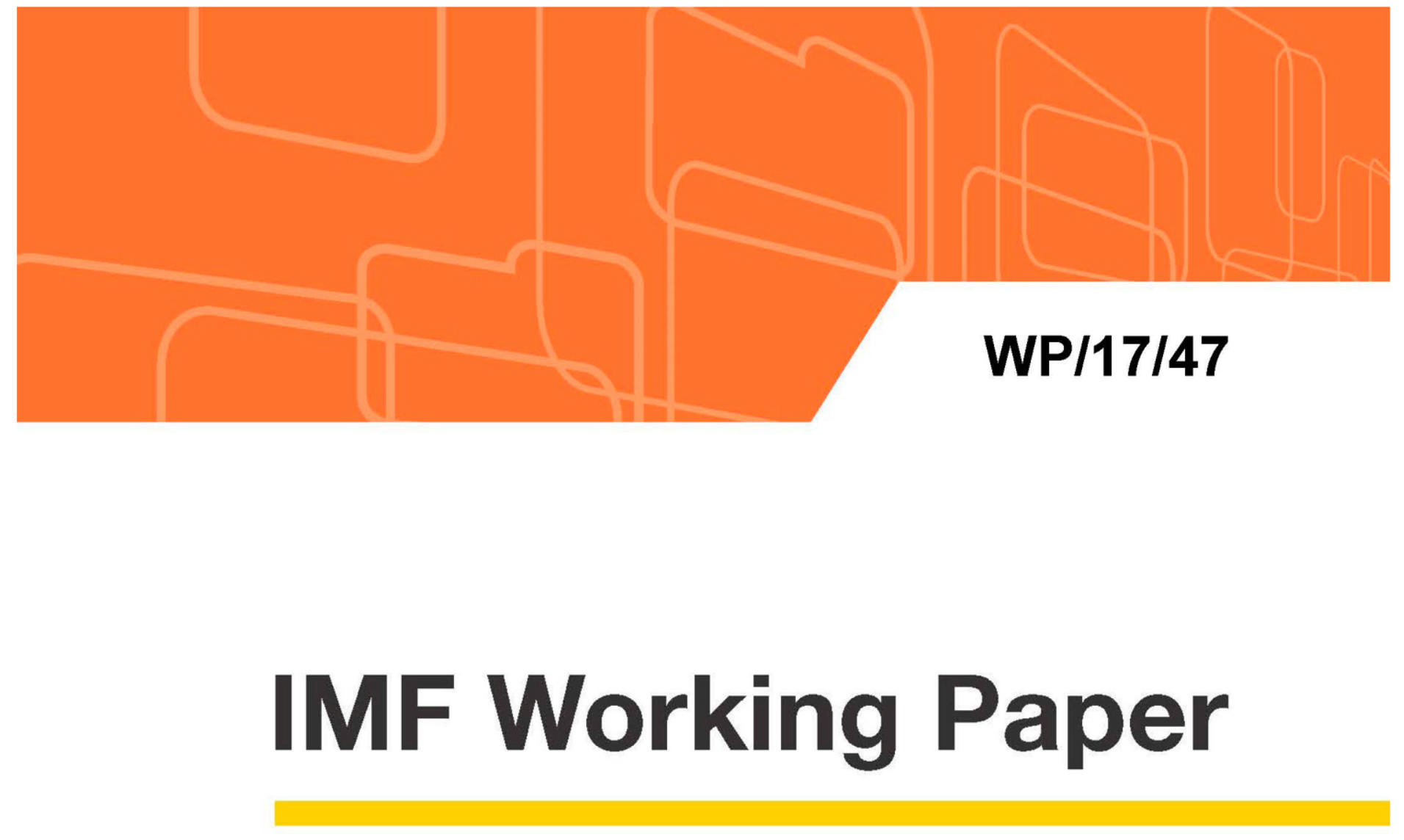

\title{
Trade Liberalization in Peru: Adjustment Costs Amidst High Labor Mobility
}

by Elin Baldárrago and Gonzalo Salinas

IMF Working Papers describe research in progress by the author(s) and are published to elicit comments and to encourage debate. The views expressed in IMF Working Papers are those of the author(s) and do not necessarily represent the views of the IMF, its Executive Board, or IMF management. 


\section{WP/17/47}

\section{IMF Working Paper}

\section{Trade Liberalization in Peru: Adjustment Costs Amidst High Labor Mobility}

by Elin Baldárrago and Gonzalo Salinas

IMF Working Papers describe research in progress by the author(s) and are published to elicit comments and to encourage debate. The views expressed in IMF Working Papers are those of the author(s) and do not necessarily represent the views of the IMF, its Executive Board, or IMF management. 


\title{
IMF Working Paper
}

Western Hemisphere Department

\section{Trade Liberalization in Peru: Adjustment Costs Amidst High Labor Mobility ${ }^{1}$ \\ Prepared by Elin Baldárrago and Gonzalo Salinas}

Authorized for distribution by Valerie Cerra

March 2017

\begin{abstract}
IMF Working Papers describe research in progress by the author(s) and are published to elicit comments and to encourage debate. The views expressed in IMF Working Papers are those of the author(s) and do not necessarily represent the views of the IMF, its Executive Board, or IMF management.
\end{abstract}

\begin{abstract}
While trade integration has been an engine of global growth and prosperity some sectors have been negatively affected by increased imports competition, as expected in theory. Higher labor mobility could lower these adjustment costs. This paper measures the cost of trade integration in a context of high internal migration. Specifically, we focus on the 200414 period of trade liberalization in Peru (a major beneficiary of trade integration). Despite significant migration in response to lower tariffs, we find a significant negative relation between tariff reduction and socioeconomic indicators of imports-competing districts. This underscores the need for policy action to support the "losers from trade liberalization".
\end{abstract}

JEL Classification Numbers: F13, I32, O18, O19, O24

Keywords: Trade Liberalization, Poverty, Peru, Tariff

Authors’ E-Mail Address: gsalinas@imf.org

\footnotetext{
${ }^{1}$ Prepared by Elin Baldarrago (Universidad Católica San Pablo, Perú) and Gonzalo Salinas (WHD) as a background paper in the IMF Cluster Report on "Trade Integration in Latin America and the Caribbean". For their extremely valuable comments, we would like to thank Valerie Cerra and participants at our seminar at the IMF's Western Hemisphere Department, as well as Marco Vega and Nikita Cespedes at Peru's Central Bank. The usual disclaimer applies.
} 
Contents Page

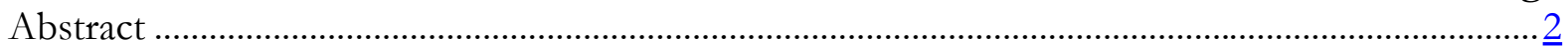

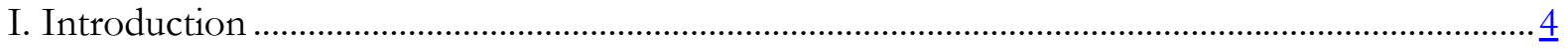

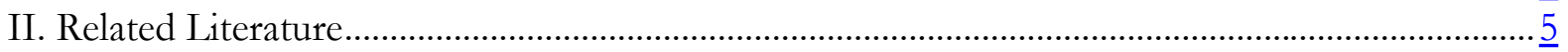

III. The Trade Liberalization Episode ……………………………………………………………

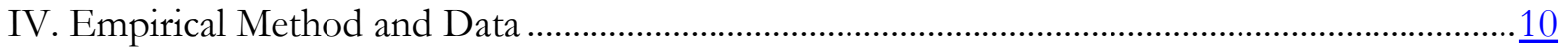

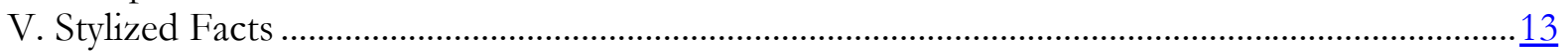

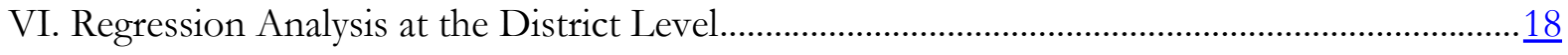

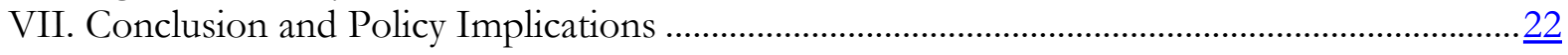

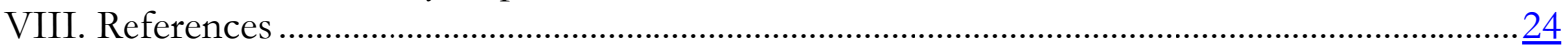

\section{Tables}

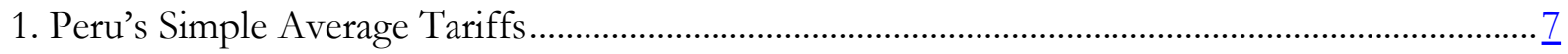

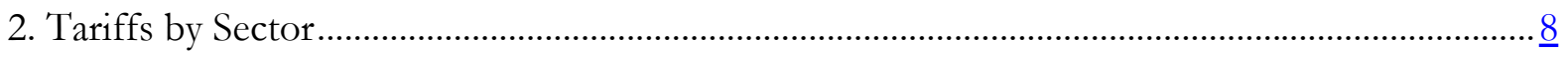

3. Change in Socioeconomic Indicators by Area, 2004-14 …………………………………........ 2

4. Regressing Tariff Levels on Previous Year's Productivity by Industry ………………………... $\frac{12}{12}$

5. Regressing Changes in Tariffs (2007-14) on Change in Social Indicators (2004-07)...................13

6. Simple Average of Main Variables Across Districts................................................................

7a. Change in Average Tariffs by Area, 2004-14 .................................................................... 15

7b. Change in Tariffs by Region, 2004-11 ……………………………………………………. $\frac{15}{15}$

8. Change in Socioeconomic Indicators by Region, 2004-14 .......................................................... 16

9. Regressing Social Indicators on Tarff Levels...........................................................................

10. Regressing Social Indicators on Tariff Levels (Excluding Non-Tradables), 2004-14 ...............19

11. Regressing Social Indicators on Tariff Levels by Type of District Tariff .................................20

12. Regressing Social Indicators on Tariff Levels (Excluding Non-Tradables) by Panel Type...... $\underline{21}$

13. Cross-Section Regression of Changes in Social Indicators on Changes in Tariffs, 2007-14..21

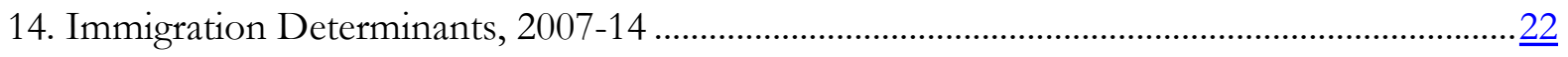

\section{Figures}

1. Imports Relevance and Log Expenditure per Person ................................................................ 13

2. Change in Average Tariffs and Social Indicators by Department, 2004-14................................ 16

3. Change in Tariffs (Including Non-Tradables) and Change in Social Indicators, 2004-14 .........17

4. Change in Tariffs (Excluding Non-Tradables) and Change in Social Indicators, 2004-14........18 


\section{INTRODUCTION}

While decades of trade liberalization and integration have fostered global economic growth, it is increasingly evident that more needs to be done to properly take into account the "losers" from these processes. With still substantial policy restrictions to the international exchange of goods and services, trade liberalization and trade integration are far from over. Although tariffs and non-tariff barriers in developing countries have been substantially lowered in recent decades, they are still considerably above the average rate in advanced countries. And in both advanced and developing countries, there are important products that remain protected actually because of their economic and political significance. Further reduction in trade policy barriers is expected to take the global economy closer to Pareto Optimality, but as in any large change in an economic system, collateral costs are expected. In the case of trade liberalization, the costs are taken by economic agents involved in production that competes with liberalized imports.

A still debated question is to what extent can labor migration washout the collateral costs of trade liberalization. The empirical literature has identified the negative impact of trade liberalization/integration on imports-competing localities (for example, Topalova, 2010; Kovak, 2013), but in a world with increasing labor mobility, both at the international and intranational level, the benefits of liberalization are expected to be spread more widely over time and eventually benefit the initial "losers". In fact, Topalova (2010) finds that the negative impact of liberalization on imports-competing sectors is insignificant and not robust in segments of the population that are more mobile. On the other hand, Autor and others (2013) for the case of the United States and Kovak (2013) and Dix-Carneiro and Kovak (2016) for the case of Brazil find a significant and negative impact of increasing trade integration on imports-competing localities, despite having considerably higher labor mobility than is the case in India. Methodological difficulties faced by some of these studies, such as the occurrence of simultaneous structural reforms and inaccurate measurement of effective imports liberalization, weaken their conclusions.

To further explore the role of labor mobility in regulating the impact of trade liberalization on its "losers", this paper analyzes the significant imports liberalization that took place in Peru in the 2000s, focusing on its impact on economic patterns and migration. This liberalization episode was not undertaken in the context of a broad-based structural reform program nor did it involve significant reductions in non-tariff barriers, and thus can be accurately measured through changes in tariffs. Based on annual tariff and household survey data throughout the period, it uses panel regressions that relate socioeconomic indicators at the district level to the district exposure to tariff reductions. We find that socioeconomic indicators were relatively more negative in districts that faced more competition as a result of imports liberalization despite indications that labor migrated in response to tariff reductions.

We first discuss, in Section II, the literature on the impact of trade policy changes on importscompeting producers, emphasizing the different methodologies and economic context of each study. Based on comprehensive tariff and socioeconomic data during the period under analysis, in Section III we describe the main features of the trade liberalization episode in Peru during the 2000s. Section IV presents our methodology and data sources, as well as potential methodological concerns. In Section V we present some stylized facts of the liberalization event 
at the district level, before proceeding to implement regression analysis in Section VI. Section VII presents conclusions and policy implications.

\section{RELATED LITERATURE}

Lower restrictions to international trade are expected to increase domestic output as a country specializes along its comparative advantages, gains access to larger economies of scale, and benefits from the international transfer of technology. Yet, these overall benefits partly involve the reallocation of production factors and an adjustment process that can significantly reduce the income of some economic agents. Reductions in restrictions to imports allows them to compete more favorably with domestically produced goods, and this can lower the income of factors involved in their local production. Restrictions to factor mobility and thus to factor reallocation to internationally competitive sectors, can considerably lengthen this negative effect. As lowincome segments of the population obtain a larger share of their income by supplying labor, labor mobility is key to "wash out" any negative effect from trade integration on the most vulnerable.

Thus, while increasing integration of the global economy has pulled out a large share of the world out of poverty, there is increasing concern about its negative impact on some segments of the population, especially among the poor. Following a period in which empirical analysis largely focused on estimating the impact of trade integration on output growth, studies on its impact on poverty and specific economic sectors gradually gained prominence. Several studies focused on the impact of liberalization on overall poverty. The main cross-country studies did not find significant evidence of an impact on poverty (for example, Krueger, 1983; Dollar and Kraay 2001; Beck and others, 2007), although some later studies found evidence of a poverty-reducing impact conditional on other factors such as institutional settings (see Sindzingre, 2005; Haltiwanger, 2011; McMillan and Verduzco, 2011; Newfarmer and Sztajerowska 2012; and Le Goff and Singh, 2013). At the country level, Porto (2004) focused on the labor income channel finding a poverty-reducing impact of liberalization in Argentina (Porto, 2004), while Goldberg and Pavcnik (2004) found no significant impact on poverty in the urban areas of Colombia (Goldberg and Pavcnik, 2004). Another branch of the literature focused on the labor market and based on cross-country (Felbermayr and others, 2011) and country-specific analysis (Hasan and others, 2012, for the case of India) some studies found that trade liberalization is associated with lower unemployment.

With growing social and political concern on the "losers" from liberalization, the empirical literature has increasingly focused on identifying and quantifying the specific impact of increased integration on imports-competing producers. A seminal analysis in Topalova $(2005,2010)$ using a Difference-in-differences approach with district level data focused on trade liberalization in India in the 1990s and found that lower tariffs did exacerbate poverty and reduced spending per capita in imports-competing districts. As expected in theory, this effect is considerably stronger among the least geographically mobile segments at the bottom of the income distribution, and in states where inflexible labor laws restrict factor reallocation across sectors. In fact, in the most mobile segments of the population the relations between tariff reductions and changes in poverty and expenditure become insignificant and/or sensitive to changes in regression specification. 
Topalova (2010) findings on the impact of mobility thus opens up the possibility that "losers" from trade liberalization in countries without legal or cultural restrictions to migration could fare better in the medium to long run. However, Autor and others (2013) identify a significant relation between increased imports-competition (from China) and reduced wages in the long run in the United States, despite the absence of legal or cultural barriers to labor mobility. This study finds no significant population adjustment for local labor markets with substantial exposure to imports, thus suggesting that the labor mobility response needed to help workers adjust to increased imports competition may be insufficient even in countries without legal or cultural restrictions to trade. Similarly, using an analysis at the level of localities as in Topalova (2010), Kovak (2013) and Dix-Carneiro and Kovak (2016) find an association between lower trade barriers faced by imports-competing producers and lower wages in Brazil, another country without significant legal or cultural barriers to labor mobility. These findings seem to contradict those in Topalova (2010) unless one assumes that the mobile segments of the population in India are more mobile than the overall populations in Brazil and the United States are (an arguable hypothesis) and therefore further analysis is needed to assess how much can labor mobility alleviate the negative impact of trade liberalization.

Some methodological difficulties faced in Topalova (2010), Kovak (2013), and Dix-Carneiro and Kovak (2016) are worth noting before deriving strong conclusions from these studies. All of them are event studies, but their trade liberalization episode took place in the context of structural adjustment programs in which other substantial changes to the macroeconomic policy framework were implemented, thus adding considerable noise to their analysis. In addition, these events included major changes to non-tariff barriers, and therefore it is harder to measure the resulting change in imports restrictiveness than would be the case if they only included changes in tariff rates (non-tariff coverage ratios are only rough measures of restrictiveness). And partly because the events took place more than two decades ago, these studies rely on databases that integrate samples taken through different methodologies, use industry codes with limited disaggregation, exclude the very significant informal sector, and/or have relatively few observations, which is a major drawback when analyzing subsamples.

Most of these drawbacks can be addressed by focusing on the recent and substantial trade liberalization episode in Peru during the 2000s. No other significant economic reforms took place during this period as the structural adjustment process was largely completed in the 1990s. As opposed to the liberalization in the 1990s, the liberalization during the 2000s was centered on tariff reductions not on lowering non-tariff barriers, and therefore the change in trade policy restrictiveness is measured more accurately through the changes in tariff rates. Another advantage of focusing on this liberalization episode is that the Peruvian government produced annual household surveys since the early 2000s, which not only provide a larger number of observations, but also a methodologically homogeneous panel with more disaggregated industry codes and a more comprehensive set of indicators, including on migration. Tariff data by tariff line and country source is also available on a yearly basis throughout this liberalization episode.

\section{The Trade Liberalization Episode}

After its significant trade liberalization in the 1990s Peru implemented additional liberalization during the 2000s. While the former episode was part of a structural reform program aimed to bring back economic growth after decades of stagnation, the latter was undertaken amidst one of the fastest economic growth episodes that the country has ever recorded. 
Another difference between the two liberalization episodes is that while the 1990s liberalization was mainly unilateral, the 2000s liberalization was implemented through several bilateral and regional liberalization agreements. Among bilateral liberalizations, the most relevant were the Free Trade Agreements (FTAs) implemented with the United States (since 2009) and with China (since 2010) considering their share of Peru's total imports. While Peru also signed an FTA with Chile (another major source of imports), tariffs to imports from that country were already very low before the FTA. The most significant regional liberalizations in terms of shares of Peru's total imports were the gradual liberalization agreed with the countries of the South American Common Market (MERCOSUR) and with the Community of Andean Nations (CAN). The latter process deepened an earlier liberalization launched in the 1990s.

The earlier reduction in trade barriers in the 1990s focused on both non-tariff and tariff barriers and largely dismantled the highly protectionist regime that was set up two decades earlier as part of an imports substitution industrialization strategy. The 1990s reforms rationalized tariffs, brought MFN tariffs down from an average of almost 70 percent in 1990 to less than 20 percent by 1993, reduced non-tariff barriers coverage to negligible levels, and eliminated foreign exchange market controls. Since 1993 MFN tariffs were gradually further reduced, reaching a simple average of 10.4 percent by 2004 .

\begin{tabular}{|c|c|c|c|}
\hline \multicolumn{4}{|c|}{$\begin{array}{c}\text { Table 1. Peru's Simple Average Tariffs } \\
\text { (MFN, Preferential to Relevant Partners, and Weighted by Source Countries, 2004-2014, in \%) }\end{array}$} \\
\hline & 2004-07 & 2008-11 & 2012-14 \\
\hline Argentina & 7.9 & 3.2 & 0.5 \\
\hline Brazil & 7.8 & 2.4 & 0.5 \\
\hline Chile & 2.2 & 0.3 & 0.0 \\
\hline China & 10.0 & 4.6 & 2.5 \\
\hline Colombia & 7.9 & 0.4 & 0.0 \\
\hline Ecuador & 9.1 & 4.1 & 0.5 \\
\hline United States & 10.0 & 2.4 & 0.7 \\
\hline Most-Favored-Nation & 10.0 & 4.8 & 3.1 \\
\hline Weighted By Source Countries 1/ & 9.1 & 3.9 & 2.2 \\
\hline $\begin{array}{l}\text { Source: UNCTAD's Trade Analysis Info } \\
1 / \text { Tariffs are weighted by countries' sha }\end{array}$ & NS) and aut & lates. & \\
\hline
\end{tabular}


Although milder than the 1990s reform, the liberalization of the late 2000s was still very significant. The 2000s liberalization implemented large reductions in tariffs to important sectors that remained highly protected after the 1990s liberalization partly because of their political sensitivity and economic significance (for example, agriculture and textiles). As seen in Table 1, the simple average of MFN tariffs and preferential tariffs to the main imports source countries came down considerably between 2004 and 2014. In fact, preferential tariffs to Peru's major sources of imports almost vanished between 2004 and 2014, while the average MFN tariff also came down considerably. The average tariff weighted by each country's share of Peru's total imports (the bottom tariff in Table 1) came down from 9.7 percent in 2004 to 1.4 percent in 2014. The most significant reductions in tariffs took place between 2008 and 2010, as a significant reduction in MFN tariffs in 2008 was followed by the entrance into force of the FTAs with the US (in 2009) and China (in 2010).

As seen in Table 2, which shows average tariffs (weighted by source countries) by sector, the late 2000s liberalization was strongest for animal, vegetable, food, wood, and textiles, the sectors that were most protected by 2004. This resulted in a more homogeneous tariff structure after liberalization, with most sectors having an average tariff below 5 percent by 2014 (except for wood and textile/clothing). Imports of minerals, metals, machinery, and electricity were left with negligible protection levels.

\section{Table 2. Tariffs by Sector (in \%)}

\begin{tabular}{lrrr}
\hline & & & Change 2004 to \\
& 2004 & 2014 \\
& & & \\
& & & \\
& & 1.5 & -11.6 \\
Animal & 13.1 & 1.9 & -10.8 \\
Vegetable & 12.7 & 2.0 & -11.7 \\
Food Products & 13.7 & 0.8 & -7.7 \\
Minerals & 8.5 & 1.2 & -5.2 \\
Fuels & 6.4 & 1.6 & -5.6 \\
Chemicals & 7.2 & 2.8 & -8.2 \\
Plastic or Rubber & 11.1 & 2.4 & -6.9 \\
Hides and Skins & 9.3 & 6.3 & -9.7 \\
Wood & 16.0 & 5.6 & -9.9 \\
Textiles and Clothing & 15.6 & 1.5 & -6.8 \\
Footwear & 8.3 & 0.8 & -7.0 \\
Stone and Glass & 7.8 & 0.6 & -6.8 \\
Metals & 7.4 & 1.0 & -7.0 \\
Machinery and Electricity & 8.1 & 1.7 & -8.2 \\
Transportation & 9.8 & & \\
& & & \\
\hline
\end{tabular}

Source: UNCTAD's Trade Analysis Information System (TRAINS) and authors' estimates.

$1 /$ Tariffs are weighted by countries' share of Peru's total imports 
As mentioned earlier, liberalization occurred in the midst of high economic growth, which is reflected in the improvements in average expenditure and poverty indicators between 2004 and 2014 (see Table 3). During that period poverty indicators were more than halved and expenditure per capita doubled, an evolution that was broadly similar in both urban and rural areas. Interestingly though, unemployment across districts, as defined in household surveys, increased during this period although remaining at very low levels.

Socioeconomic indicators during this period improved also as a result of several programs targeting the poor. These included conditional cash transfers to districts with headcount poverty above 40 percent (Juntos), cash transfers and technical assistance to agricultural producers (Haku Wiñay), and pensions for low income elders (Pension 65). However, there were no specific social programs targeting those affected by trade liberalization.

\begin{tabular}{|c|c|c|c|c|}
\hline \multicolumn{5}{|c|}{$\begin{array}{l}\text { Table 3. Change in Socioeconomic Indicators by Area, 2004-14 } \\
\text { (Percentage points) }\end{array}$} \\
\hline & $\begin{array}{c}\text { Headcount Poverty } \\
\text { Ratio }\end{array}$ & Poverty Gap & $\begin{array}{l}\text { Expenditure per } \\
\text { person }\end{array}$ & Unemployment \\
\hline \multicolumn{5}{|c|}{ All Districts } \\
\hline 2004 & 61.2 & 25.8 & 238.7 & 1.2 \\
\hline 2014 & 27.6 & 8.6 & 497.9 & 3.5 \\
\hline Change & -33.6 & -17.2 & 259.1 & 2.3 \\
\hline \multicolumn{5}{|c|}{ Urban Districts } \\
\hline 2004 & 45.8 & 17.0 & 353.1 & 1.1 \\
\hline 2014 & 20.3 & 6.0 & 641.5 & 4.4 \\
\hline Change & -25.5 & -11.0 & 288.4 & 3.3 \\
\hline \multicolumn{5}{|c|}{ Rural Districts } \\
\hline 2004 & 70.1 & 30.6 & 173.0 & 1.2 \\
\hline 2014 & 33.6 & 10.7 & 381.6 & 2.7 \\
\hline Change & -36.5 & -19.9 & 208.6 & 1.5 \\
\hline $\begin{array}{l}\text { Source: UN } \\
\text { Notes: Tari }\end{array}$ & $\begin{array}{l}\text { System (TRAINS), Nat } \\
\text { f Peru's total imports. }\end{array}$ & nal Houshold Surv & eys, and authors' & \\
\hline
\end{tabular}




\section{EMPIRICAL METHOD AND DATA}

\section{Methodology}

To assess the potential impact of trade liberalization through the imports-competition channel, we follow a methodology similar to those used in Topalova (2010), Autor and others (2013), Kovak (2013), Dix-Carneiro and Kovak (2016), among others. As is the case in these studies, we observe the district level relation between changes in imports competition due to tariff changes and changes in socioeconomic indicators. To determine the exposure of district producers to changes in tariffs we first construct a weighted import tariff at the district level, using the following formula:

$T_{d, t}=\frac{\sum_{i} L_{d, i, 2004} \cdot T_{i, t}}{T L_{d, 2004}}$

where $\mathrm{L} d, i, 2004$ is the number of workers at district $d$ involved in economic activity $i$, in year 2004, TLd,2004 is the total number of workers at district $d$ in 2004, and Ti, $t$ is the tariff linked to the economic activity $i$ in year $t$. Equation 1 is thus an average of the tariffs linked to the economic activities performed at each district, weighted by the share of workers that were involved in each economic activity in year 2004 (the first year in our observation period). For an industry that has no tariff line (which we assume is non-tradable) we assign zero as its tariff rate.

We then analyze the relation between tariffs and socioeconomic indicators at the district level using the following fixed effects specification:

$\mathrm{y}_{\mathrm{d}, \mathrm{t}}=\alpha+\beta \mathrm{T}_{\mathrm{d}, \mathrm{t}}+\gamma_{\mathrm{t}}+\gamma_{\mathrm{d}}+\varepsilon_{\mathrm{d}, \mathrm{t}}$

where $\mathrm{d}$ is the district code, $t$ is the year of observation, $\mathrm{y}$ is a socioeconomic indicator, $\mathrm{T}$ is the district level tariff specified in equation $1, \gamma t$ is a year fixed effect, and $\gamma d$ is a district fixed effect. $\beta$ is thus the estimated relation between a change in the district level tariff and in its socioeconomic indicators. The period of analysis is 2004-2014. The socioeconomic indicators analyzed are the headcount poverty index, the poverty gap, the logarithm of average expenditure per capita, the unemployment rate, as well as the immigration ratio (the share of immigrants in a district's population) so as to get a sense of how much geographic reallocation is prompted by liberalization.

Note that the composition of labor in each district is fixed at 2004 and therefore any relation between tariff levels and social indicators is not affected by variations in labor composition as a result of variations in tariffs. This is important since, if we would not fix the composition of labor in the initial year, any strong reduction in an import tariff could result in a reduction in the share of people involved on the import-competing industry and a reduction of the weight of that product on the district tariff indicator. In that case, our district tariff indicator would not accurately reflect the economic impact of the reduction in an import tariff and we would not be able to effectively link changes in socioeconomic indicators to tariff reductions. 


\section{Data}

We construct the district-level tariffs in equation 1 based on weighted average tariffs that take into account preferential tariffs that Peru applies to imports from several countries. Specifically, these weighted average tariffs are built by multiplying the tariff applied to imports from each country times a weight that is the share of each country in Peru's total imports (this weighting is shown in Annex Table 1). For Peru's top eight sources of imports we use their specific preferential tariff and for the rest we use the MFN tariff. These estimations use tariff data from UNCTAD's Trade Integrated System (TRAINS) as extracted from the World Bank's World Integrated Trade System (WITS) at the 10-digit level classified according to the 2007 Harmonized System (HS 2007).

We link tariffs to economic activities in each district by matching tariff codes with industrial codes in household surveys. We thus match trade data with HS 2007 classification at the 10-digit level to industrial codes in household surveys that classify economic activities at the 4-digit level according to the International System of Industrial Classification (ISIC) Rev 4. This matching was largely based on a correspondence table available at the website of the United Nations Statistics Division and complemented with manual matching of missing correspondences.

Socioeconomic indicators were estimated based on National Household Surveys (Encuestas Nacionales de Hogares, ENAHOs) elaborated by Peru's National Statistics and Informatics Institute (Instituto Nacional de Estadisticas e Informatica, INEI). For each district we calculate poverty indicators based on INEI's national poverty line, as well as the average expenditure per capita, the unemployment rate, and the share of immigrants.

\section{Methodological issues}

Before undertaking our analysis we address some methodological concerns in regressing equation 2. A priori, there are political economy reasons to expect that changes in tariff levels are endogenous to changes in socioeconomic indicators. If the government avoids reducing tariff protection to low productivity sectors (and therefore poorer districts) and the latter grow at faster rates than high productivity sectors (possibly due to convergence factors), this could result in an indirect link between lower tariffs and worse socioeconomic indicators that spuriously implies that the former caused the latter.

In order to rule out this possibility we regress productivity on subsequent tariffs and thus see if tariffs have been set as to protect lower productivity sectors (as in Topalova, 2005). If less productive industries experienced lower reductions in their corresponding tariffs we would find negative coefficients of the productivity variable, but as seen in table 4 , we actually find positive and statistically insignificant coefficients. Thus, we do not see any strong evidence of political economy related endogeneity in a potential negative relation between trade barriers and socioeconomic indicators.

Regression results could also spuriously reflect a relation between past trends in socioeconomic indicators and following reductions in tariffs. In particular, it may be the case that districts in which socioeconomic indicators were improving faster before liberalization (for structural reasons that could prolong this trend during the liberalization period) were also those in which tariffs were reduced less significantly afterwards. This would generate a negative relation 
between tariff reduction and improvements in socioeconomic indicators that would not correspond to causality from the former to the latter.

Table 4. Regressing Tariff Levels on Previous Year's Productivity by Industry

\begin{tabular}{|c|c|c|c|}
\hline & \multicolumn{3}{|c|}{ Dependent Variable: Tariffs on year $t$} \\
\hline & MFN tariff & Tariff to US imports & Imports-w eighted tariffs \\
\hline \multirow[t]{2}{*}{ Productivity on year t-1 } & 4.02 & 5.06 & 4.52 \\
\hline & $(0.63)$ & $(0.59)$ & $(0.71)$ \\
\hline \multirow[t]{2}{*}{ Constant } & $9.139 * * *$ & $9.655^{* * *}$ & $9.668^{* * *}$ \\
\hline & $(0.00)$ & $(0.00)$ & $(0.00)$ \\
\hline R-squared & 0.82 & 0.78 & 0.80 \\
\hline Observations & 812 & 816 & 816 \\
\hline Number of Groups & 116 & 117 & 117 \\
\hline \multicolumn{4}{|c|}{$\begin{array}{l}\text { Notes: Coefficients and } \mathrm{p} \text {-values reported for each independent variable }(* \mathrm{p}<0.05, * * \mathrm{p}<0.01, * * * \mathrm{p}<0.001) \text {. Industry and year fixed effects are } \\
\text { used. Tariffs are weighted by countries' share of Peru's total imports. Productivity is sales-weighted average of firm level TFP as estimated in } \\
\text { Cespedes et al (forthoming) }\end{array}$} \\
\hline
\end{tabular}

To test this hypothesis, we conduct a falsification test in which pre-liberalization changes in socioeconomic indicators are regressed on tariff changes since 2007. We split the observation period in this year recalling that most of the reduction in tariffs during 2004-14 took place in 2008-2010. Results in Table 5 actually show that pre-liberalization improvements in socioeconomic indicators are positively correlated with tariff reductions after 2007 , thus rejecting the hypothesis that previous trends in socioeconomic indicators could generate a negative relation between tariff reductions and improvements in socioeconomic indicators.

Another methodological concern in implementing equation 2 results from the fact that the tariff measure estimated through equation 1 is determined not only by tariff rates, but also by the share of traded industries in a district. Since equation 1 assigns a zero tariff to non-tradable goods, districts with a higher share of non-tradable goods tend to have lower average tariffs. Therefore, they will see reductions in their average tariff of smaller magnitude not only because of changes in the tariff rates of its products. As seen in Figure 1, districts with a higher share of non-tradable goods are the geographically more isolated and poorer. And if, for instance, those districts also experience higher reductions in poverty due to non-tariff related indicators such as roads development and social assistance programs, equation 2 would register a relation between changes in tariffs and in socioeconomic indicators not solely related to the impact of the former on the latter. We deal with this possible endogeneity as in Topalova (2010) by implementing a modified version of equation 1 excluding non-tradable activities. 
Table 5. Regressing Changes in Tariffs (2007-14) on Change in Social Indicators (2004-07)

Dependent Variable: 2007-14 Changes in District Tariffs

2004-07 Change in Headcount Poverty Ratio
2004-07 Previous Change in Poverty Gap
2004-07 Previous change in Log expenditure per person

Observations
$0.011^{*}$

(0.08)

0.006

(0.44)

$-0.0050$

(0.16)

476

Notes: Coefficients and $\mathrm{p}$-values reported for each independent variable $\left(* \mathrm{p}<0.05,{ }^{*} \mathrm{p}<0.01, * * * \mathrm{p}<0.001\right)$. District and year fixed effects are used. Tariffs are weighted by countries' share of Peru's total imports.

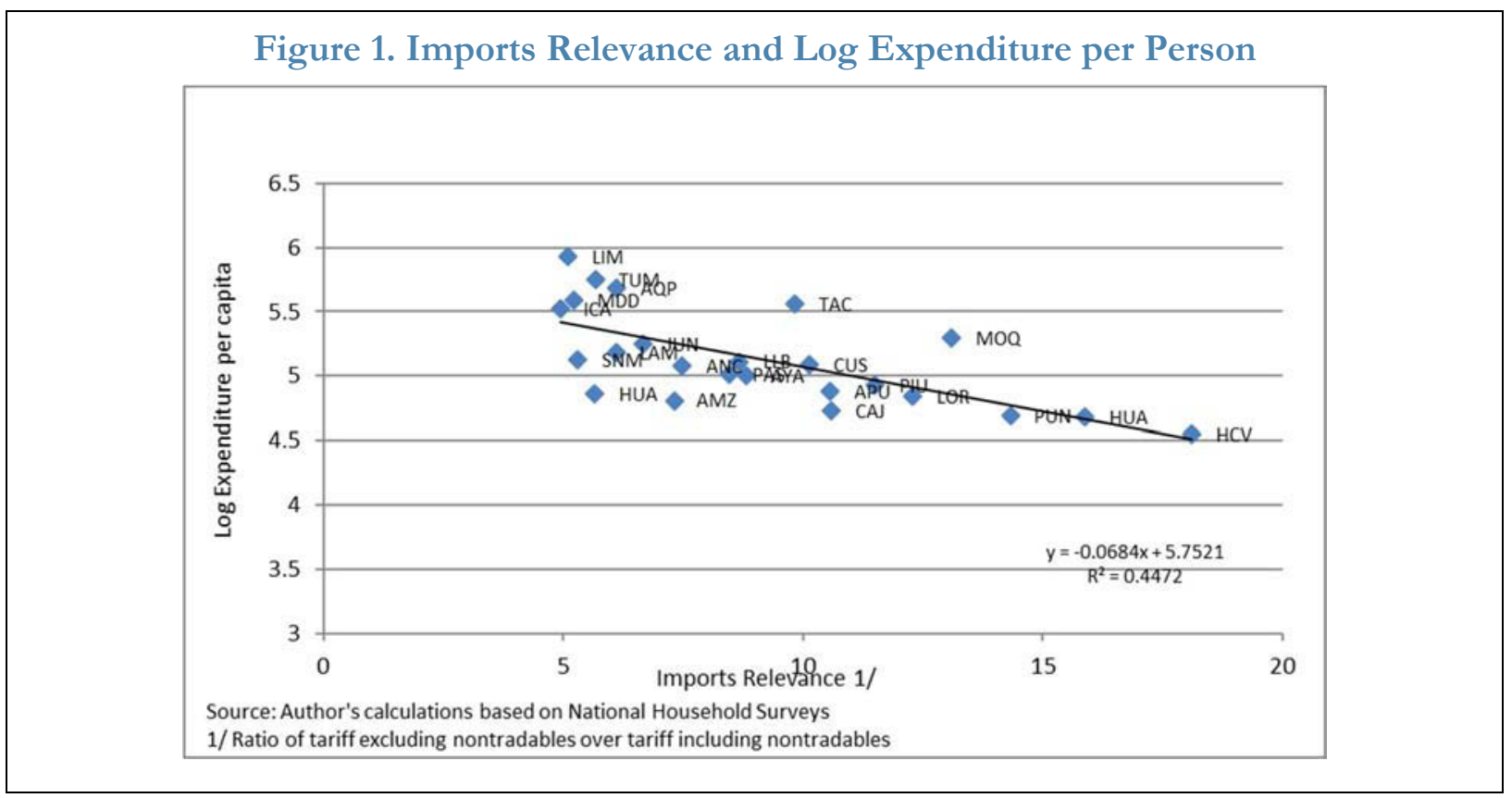

\section{STYLIZEd FACTS}

The evolution of district-level tariffs (estimated through equation 1) illustrates several features of the liberalization process and its relation to changes in districts' socioeconomic indicators. As seen in Table 6, the simple average of all district-level tariffs came down significantly from 2004 to 2014. Note that tariffs including non-tradables are much lower than the magnitude of average tariff rates shown in Table 1 because they include nontradables and assigned them a zero value, thus lowering the average rate. 
Table 6. Simple Average of Main Variables Across Districts (in \%)

2004-07 2008-11 2012-14

\begin{tabular}{|c|c|c|c|}
\hline Tariffs Including Non-Tradables 1/ & 1.8 & 0.7 & 0.3 \\
\hline Tariffs Excluding Non-Tradables 1/ & 10.4 & 3.8 & 1.8 \\
\hline Poverty headcount ratio & 56.7 & 41.0 & 29.9 \\
\hline Poverty Gap & 23.3 & 14.9 & 9.5 \\
\hline Expenditure per person (in 2004 Nuevos Soles) & 263.0 & 367.1 & 472.5 \\
\hline \multicolumn{4}{|c|}{$\begin{array}{l}\text { Source: UNCTAD's Trade Analysis Information System (TRAINS) and authors' } \\
\text { estimates. } \\
1 \text { / Tariffs are estimated based on panel balanced at the district level. Tariffs are weighted } \\
\text { by countries' share of Peru's total imports. }\end{array}$} \\
\hline
\end{tabular}

Table 7a shows that district tariff reductions were similar in rural and urban districts. In fact, in both areas both initial and final average tariffs are almost equal. Table $7 \mathrm{~b}$ presents estimated average tariffs across the main geographic areas of the country: the coast, the Andes, and the Amazon, separating the districts of the city of Lima from other coastal districts. When including nontradables, the more isolated highland districts show lower tariff reductions since those districts have a larger share of nontradables (as seen in Figure 1). When excluding non-tradables, average district tariff reductions are similar across the three geographic areas, though it appears smaller for Lima districts.

The geographic dimension of liberalization can be analyzed more deeply by looking at department level tariffs (simple average of their districts) including and excluding non-tradables, as seen in Figure 2. We corroborate our earlier finding that tariffs including non-tradables experienced the largest reduction in the more integrated coastal departments (Tumbes, Ica, Lambayeque, Lima, and La Libertad) than in the less integrated highland departments (Huancavelica, Huanuco, Cajamarca). However, when excluding non-tradables, reductions in average tariffs are more homogenous across departments, with slightly larger reductions in some highland departments that are more reliant on farm products (Junin, Ayacucho, Huancavelica) than in those less reliant on these products (Lima, Tacna, Arequipa). 
Table 7a. Change in Average Tariffs by Area, 2004-14 (Percentage Points)

\begin{tabular}{|c|c|c|}
\hline & \multicolumn{2}{|c|}{ Average Tariff } \\
\hline & $\begin{array}{l}\text { Including Non- } \\
\text { Tradables }\end{array}$ & $\begin{array}{l}\text { Excluding Non- } \\
\text { Tradables }\end{array}$ \\
\hline \multicolumn{3}{|c|}{ All Districts } \\
\hline 2004 & 2.1 & 12.3 \\
\hline 2014 & 0.3 & 1.7 \\
\hline Change & -1.8 & -10.5 \\
\hline \multicolumn{3}{|c|}{ Urban Districts } \\
\hline 2004 & 2.3 & 12.0 \\
\hline 2014 & 0.4 & 1.8 \\
\hline Change & -1.9 & -10.2 \\
\hline \multicolumn{3}{|c|}{ Rural Districts } \\
\hline 2004 & 2.0 & 12.4 \\
\hline 2014 & 0.2 & 1.6 \\
\hline Change & -1.8 & -10.8 \\
\hline
\end{tabular}

Table 7b. Change in Tariffs by Region, 2004-11 (Percentage Points)

\begin{tabular}{|c|c|c|}
\hline & \multicolumn{2}{|c|}{ Average Tariff } \\
\hline & $\begin{array}{l}\text { Including Non-Tradables } \\
\end{array}$ & $\begin{array}{l}\text { Excluding Non-Tradables } \\
\end{array}$ \\
\hline \multicolumn{3}{|c|}{ All Districts } \\
\hline 2004 & 2.1 & 12.3 \\
\hline 2011 & 0.3 & 1.7 \\
\hline Change & -1.8 & -10.5 \\
\hline \multicolumn{3}{|c|}{ Coastal Districts (excluding Lima) } \\
\hline 2004 & 3.2 & 12.7 \\
\hline 2011 & 0.4 & 1.7 \\
\hline Change & -2.8 & -11.0 \\
\hline \multicolumn{3}{|c|}{ Highland Districts } \\
\hline 2004 & 1.5 & 12.2 \\
\hline 2011 & 0.2 & 1.6 \\
\hline Change & -1.3 & -10.6 \\
\hline \multicolumn{3}{|c|}{ Rainforest Districts } \\
\hline 2004 & 2.6 & 12.2 \\
\hline 2011 & 0.3 & 1.5 \\
\hline Change & -2.2 & -10.7 \\
\hline \multicolumn{3}{|c|}{ Lima City Districts } \\
\hline 2004 & 2.4 & 11.4 \\
\hline 2011 & 0.5 & 2.5 \\
\hline Change & -1.9 & -8.9 \\
\hline
\end{tabular}

C)International Monetary Fund. Not for Redistribution 
Figure 2. Change in Average Tariffs and Social Indicators by Department, 2004-14, in percentage points $1 /$
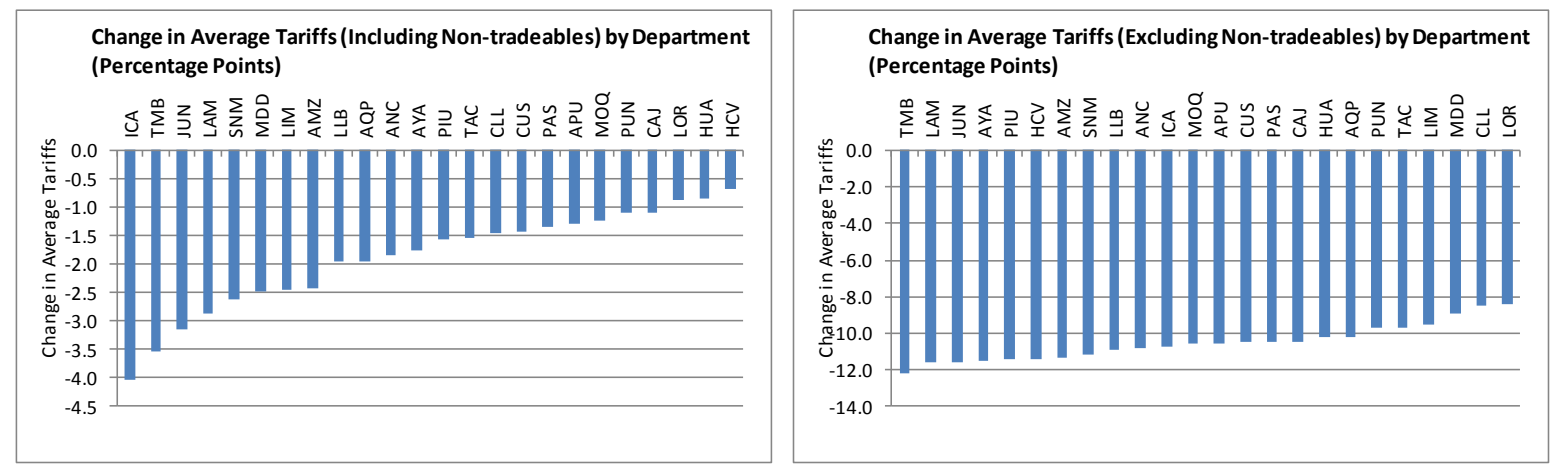

Source: Authors' calculations based on World Bank WITS database and Peruvian National Household Surveys

Regarding the evolution of socioeconomic indicators, we observe in Table 8 that all regions exhibited the same pattern of significant declines in poverty, increases in expenditure per capita, and slight increases in unemployment. Socioeconomic improvements are important in all geographic regions although with some heterogeneity. Headcount poverty fell more in the wealthier and more modern coastal region, but it also fell substantially in the poorer and more isolated rainforest and highland regions. On the other hand, expenditure per person increased more homogeneously across all major regions of the country.

Table 8. Change in Socioeconomic Indicators by Region, 2004-14

\section{(Percentage Points)}

\begin{tabular}{|c|c|c|c|c|}
\hline & $\begin{array}{c}\text { Headcount Poverty } \\
\text { Ratio }\end{array}$ & Poverty Gap & Expenditure per person & Unemployment \\
\hline \multicolumn{5}{|c|}{ All Districts } \\
\hline 2004 & 61.2 & 25.8 & 238.7 & 1.2 \\
\hline 2014 & 27.6 & 8.6 & 497.9 & 3.5 \\
\hline Change & -33.6 & -17.2 & 259.1 & 2.3 \\
\hline \multicolumn{5}{|c|}{ Coastal Districts (excluding Lima) } \\
\hline 2004 & 46.1 & 15.9 & 288.0 & 1.1 \\
\hline 2014 & 13.7 & 4.4 & 595.5 & 4.5 \\
\hline Change & -32.4 & -11.5 & 307.5 & 3.3 \\
\hline \multicolumn{5}{|c|}{ Highland Districts } \\
\hline 2004 & 69.5 & 31.5 & 184.2 & 1.4 \\
\hline 2014 & 36.1 & 11.2 & 389.1 & 3.0 \\
\hline Change & -33.4 & -20.3 & 204.9 & 1.6 \\
\hline \multicolumn{5}{|c|}{ Rainforest Districts } \\
\hline 2004 & 67.0 & 26.9 & 191.2 & 0.8 \\
\hline 2014 & 28.4 & 8.1 & 445.8 & 2.9 \\
\hline Change & -38.5 & -18.8 & 254.6 & 2.1 \\
\hline \multicolumn{5}{|c|}{ Lima City Districts } \\
\hline 2004 & 31.4 & 8.9 & 601.2 & 0.6 \\
\hline 2014 & 6.2 & 1.5 & 1101.3 & 5.4 \\
\hline Change & -25.2 & -7.3 & 500.1 & 4.8 \\
\hline
\end{tabular}


Scatter plots of the estimated changes in tariffs and socioeconomic indicators at the department level give us a first glance at the relation between them during the trade liberalization period. When including non-tradables, reductions in average tariffs are negatively and significantly correlated to improvements in poverty and expenditure per person, as seen in Figure 3. As discussed in an earlier section, this relation could be spurious and largely related to the share of non-tradables in the basket of goods produced across districts. This concern is heightened when we observe that the correlation between tariff reductions and poverty indicators is much weaker when estimating tariffs by excluding non-tradables, as seen Figure 4. On the other hand, reductions in tariffs excluding non-tradables remain strongly related to increases in expenditure per person. Regressions at the district level give us a more precise measurement of this relation.

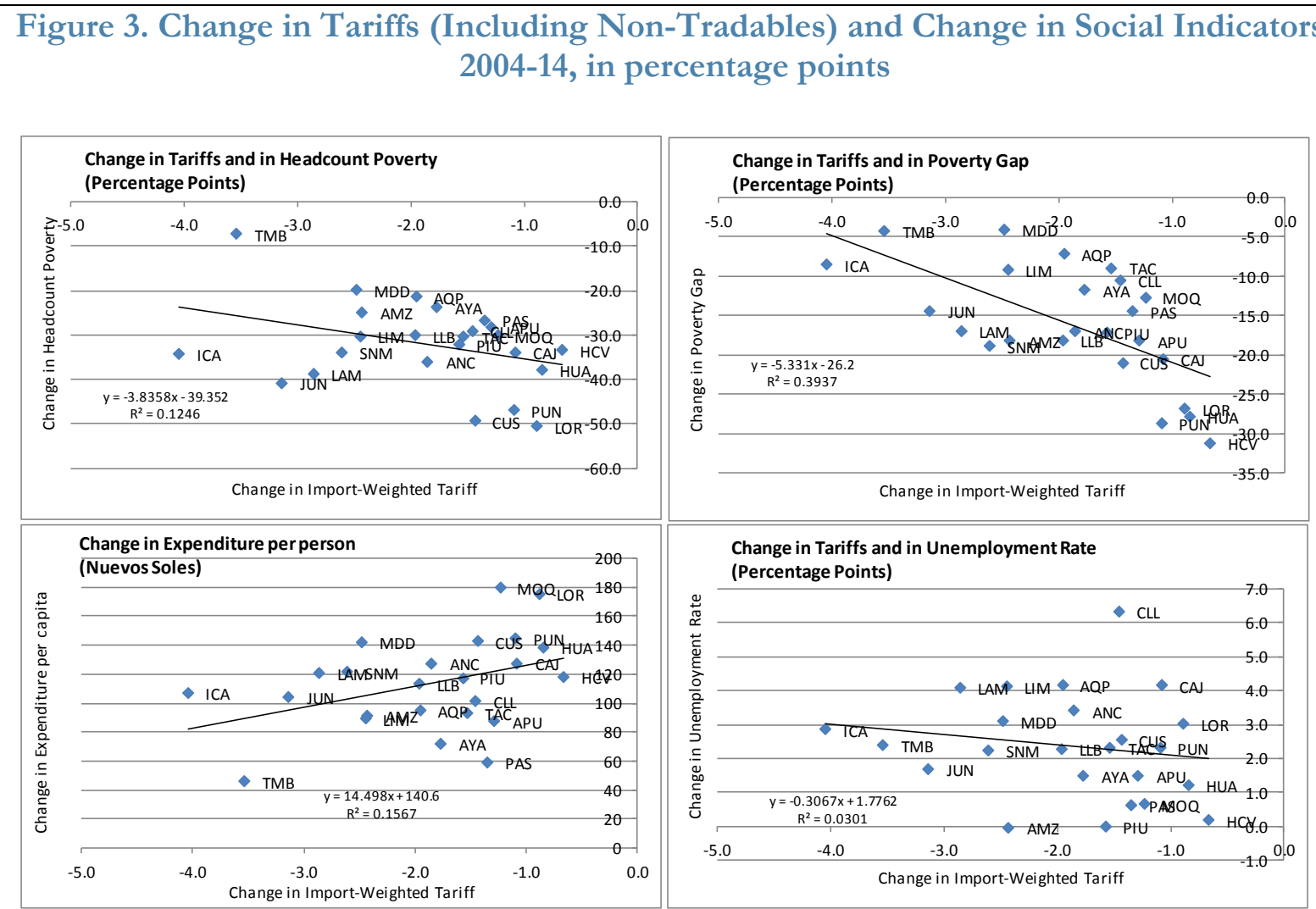




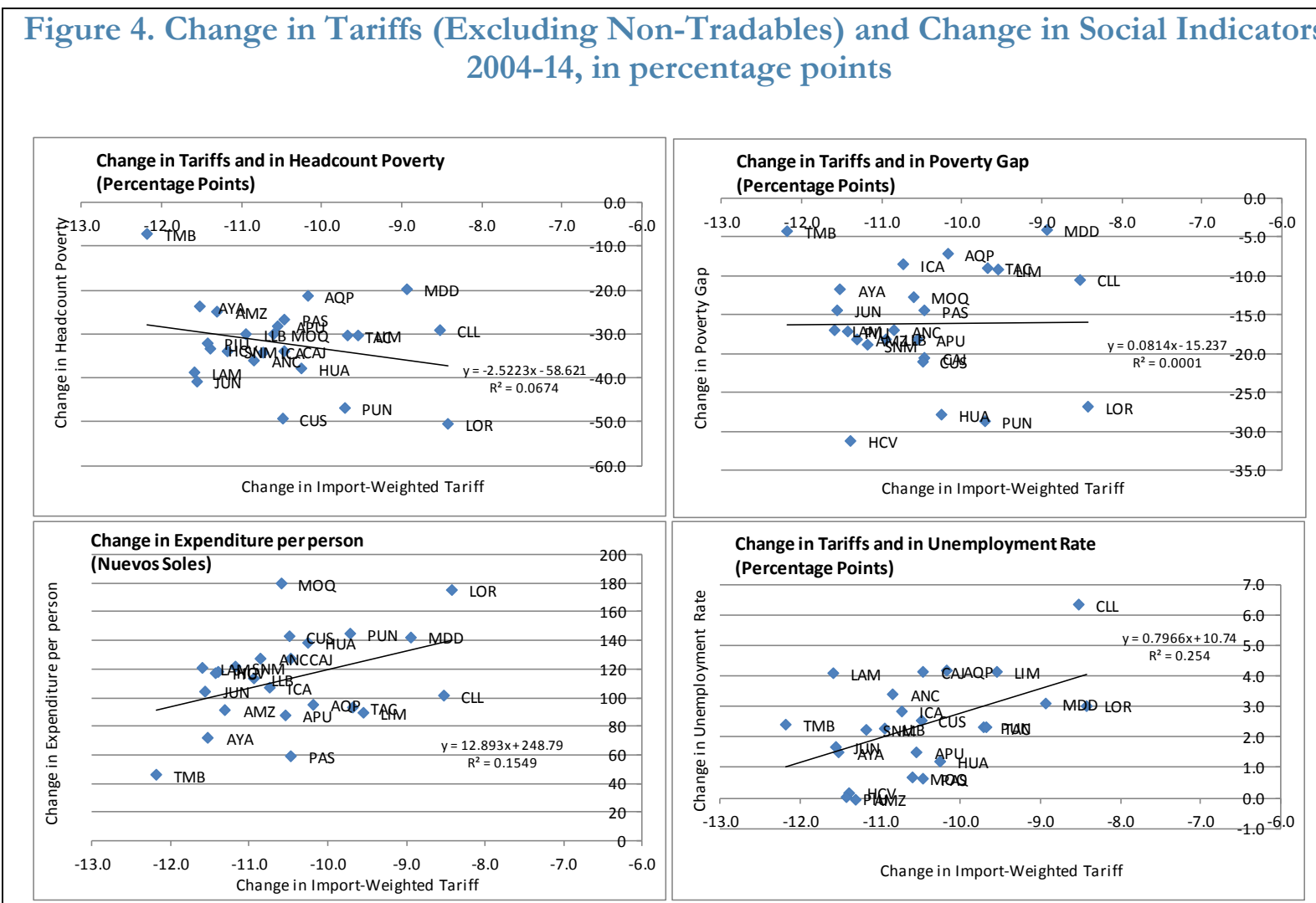

\section{Regression ANALYsis AT THE District LEVEL}

District level regressions confirm that tariff reductions are significantly associated with changes in socioeconomic indicators in the high labor mobility context of the Peruvian economy. We first regress socioeconomic indicators on district tariffs that are calculated including non-tradable products. Results presented in Table 9 corroborate scatter plot indications of the significant relation between changes in tariffs and changes in poverty indicators, expenditure per person, and the unemployment rate. Again we underscore that this statistical relation could be a spurious result from including non-tradables in the calculation of district level tariffs. 


\begin{tabular}{|c|c|c|c|c|}
\hline \multicolumn{5}{|c|}{$\begin{array}{l}\text { Table 9. Regressing Social Indicators on Tarff Levels } \\
\qquad \text { (Balanced Panel, 2004-14) }\end{array}$} \\
\hline & $\begin{array}{c}\text { Headcount } \\
\text { Poverty Ratio }\end{array}$ & Poverty Gap & $\begin{array}{l}\text { Log expenditure } \\
\text { per person }\end{array}$ & Unemployment \\
\hline District Level Tariffs & $\begin{array}{r}-0.751 * * \\
(0.02)\end{array}$ & $\begin{array}{r}-2.072^{* * *} \\
(0.00)\end{array}$ & $\begin{array}{r}2.44 * * * \\
(0.00)\end{array}$ & $\begin{array}{r}0.18^{* * *} \\
(0.04)\end{array}$ \\
\hline Constant & $\begin{array}{r}0.628^{* * *} \\
(0.00)\end{array}$ & $\begin{array}{r}0.306^{* * *} \\
(0.00)\end{array}$ & $\begin{array}{r}5.074 * * * \\
(0.00)\end{array}$ & $\begin{array}{r}0.008^{* *} \\
(0.00)\end{array}$ \\
\hline $\begin{array}{l}\text { R-squared } \\
\text { Observations }\end{array}$ & $\begin{array}{r}0.39 \\
5874\end{array}$ & $\begin{array}{r}0.38 \\
5512\end{array}$ & $\begin{array}{r}0.64 \\
5874\end{array}$ & $\begin{array}{r}0.13 \\
5874\end{array}$ \\
\hline
\end{tabular}

We thus implement again equation 2 , this time by excluding non-tradables in estimating equation 1. Results in Table 10 show that tariffs are still positively associated with higher expenditure and lower poverty, and the statistical significance remains strong. A ten percent reduction in tariffs is associated with a 2.9 percentage point increase in headcount poverty, a 2.3 percentage point increase in the poverty gap, a 7.6 percent decrease in expenditure per person, and a 1.8 percentage point decrease in unemployment. Table 10. Regressing Social Indicators on Tariff Levels (Excluding Non-Tradables),
2004-14

\begin{tabular}{|c|c|c|c|c|}
\hline & $\begin{array}{c}\text { Headcount Poverty } \\
\text { Ratio }\end{array}$ & Poverty Gap & $\begin{array}{l}\text { Log expenditure } \\
\text { per person }\end{array}$ & Unemployment \\
\hline District Level Tariffs (excl. non-tradeables) & $\begin{array}{r}-0.292 * \\
(-0.09)\end{array}$ & $\begin{array}{r}-0.230^{* *} \\
(-0.02)\end{array}$ & $\begin{array}{r}0.791^{* *} \\
(0.00)\end{array}$ & $\begin{array}{r}0.182^{* * * *} \\
(0.00)\end{array}$ \\
\hline Constant & $\begin{array}{r}0.616^{* * *} \\
(0.00)\end{array}$ & $\begin{array}{r}0.272^{* * *} \\
(0.00)\end{array}$ & $\begin{array}{r}5.112^{* * *} \\
(0.00)\end{array}$ & $\begin{array}{r}5.112^{* * *} \\
(0.00)\end{array}$ \\
\hline $\begin{array}{l}\text { R-squared } \\
\text { Observations }\end{array}$ & $\begin{array}{r}0.387 \\
5236\end{array}$ & $\begin{array}{r}0.362 \\
4893\end{array}$ & $\begin{array}{r}0.641 \\
5236\end{array}$ & $\begin{array}{r}0.641 \\
5236\end{array}$ \\
\hline
\end{tabular}

\section{CInternational Monetary Fund. Not for Redistribution}


Interestingly, the tariff coefficient on headcount poverty is similar to the coefficient found in Topalova (2010) for rural India even though Peru's labor mobility in the 2000s is most likely higher than in rural India in the 1990s. In addition, the tariff coefficient on log of expenditure per capita is statistically significant (this coefficient is not significant for neither rural or urban India). These stronger results despite the higher labor mobility in Peru could be the result of more precise estimates due to the methodological advantages of our database, as described earlier.

The statistical significance of these results is robust to a number of methodological variations. Table 11 presents the results of regressing equation 2 using district tariffs calculated including and excluding non-tradables, as well as using two additional instrumental variables used in Topalova (2010) to control for the potential spuriousness of using district tariffs calculated including non-tradables. The statistical and economic significance of the coefficient appears robust, except for the coefficient of unemployment. The magnitude of the coefficients when using the last two instrumental variables as tariff measures is higher than when using the second instrumental variable as these last two IVs are considerably lower in magnitude than the second IV by construction. Results are also statistically robust if we include districts for which we do not have data for all years during the liberalization period (unbalanced panel) as opposed to the balanced panel used in previous regressions (see Table 12), as well as if we run a cross section version of equation 2 considering changes in the variables between 2007 (before the strongest liberalizations of 2008-10) and 2014 (see Table 13).

Table 11. Regressing Social Indicators on Tariff Levels by Type of District Tariff

\begin{tabular}{|c|c|c|c|c|}
\hline & $\begin{array}{c}\text { Headcount Poverty } \\
\text { Ratio }\end{array}$ & Poverty Gap & $\begin{array}{l}\text { Log expenditure per } \\
\text { person }\end{array}$ & Unemployment \\
\hline \multicolumn{5}{|c|}{ Tarifs including non-tradeables } \\
\hline District Level Tariffs & $\begin{array}{r}-0.751 * * \\
(-0.02)\end{array}$ & $\begin{array}{r}-2.072 * * * \\
(0.00)\end{array}$ & $\begin{array}{r}2.44 * * * \\
(0.00)\end{array}$ & $\begin{array}{r}0.18 * * * \\
(0.04)\end{array}$ \\
\hline Observations & 5874 & 5512 & 5874 & 5874 \\
\hline \multicolumn{5}{|c|}{ Tariffs excluding non-tradeables } \\
\hline District Level Tariffs & $\begin{array}{r}-0.292 * \\
(-0.09)\end{array}$ & $\begin{array}{r}-0.230 * * \\
(-0.02)\end{array}$ & $\begin{array}{r}0.791 * * \\
(0.00)\end{array}$ & $\begin{array}{r}0.182^{* * *} \\
(0.00)\end{array}$ \\
\hline Observations & 5236 & 4893 & 5236 & 5236 \\
\hline \multicolumn{5}{|c|}{ IV Tariff based on $2 S L S$} \\
\hline District Level Tariffs & $\begin{array}{l}-1.59 * \\
(-0.09)\end{array}$ & $\begin{array}{r}-1.206 * * \\
(-0.02)\end{array}$ & $\begin{array}{r}4.308^{* * *} \\
(0.00)\end{array}$ & $\begin{array}{l}3.554 \\
(0.21)\end{array}$ \\
\hline Observations & 5236 & 4893 & 5236 & 5236 \\
\hline \multicolumn{5}{|c|}{ Tariff excluding tradeables and initial tariff as $I V$} \\
\hline District Level Tariffs & $\begin{array}{r}-2.789 * * \\
(-0.02)\end{array}$ & $\begin{array}{r}-2.934 * * * \\
(0.00)\end{array}$ & $\begin{array}{r}7.110^{* * *} \\
(0.00)\end{array}$ & $\begin{array}{l}0.477 \\
(0.12)\end{array}$ \\
\hline Observations & 4760 & 4431 & 4760 & 4760 \\
\hline
\end{tabular}




\section{Table 12. Regressing Social Indicators on Tariff Levels (Excluding Non-Tradables) by Panel Type}

\begin{tabular}{|c|c|c|c|c|}
\hline & $\begin{array}{c}\text { Headcount Poverty } \\
\text { Ratio }\end{array}$ & Poverty Gap & $\begin{array}{l}\text { Log expenditure per } \\
\text { person }\end{array}$ & Unemployment \\
\hline \multicolumn{5}{|c|}{ Panel balanced at district level (2004-14) } \\
\hline District Level Tariffs & $\begin{array}{r}-0.292^{*} \\
(-0.09)\end{array}$ & $\begin{array}{r}-0.230 * * \\
(-0.02)\end{array}$ & $\begin{array}{r}0.791 * * \\
(0.00)\end{array}$ & $\begin{array}{r}0.182^{* * *} \\
(0.00)\end{array}$ \\
\hline Observations & 5236 & 4893 & 5236 & 5236 \\
\hline \multicolumn{5}{|c|}{ Unbalanced Panel (2004-14) } \\
\hline District Level Tariffs & $\begin{array}{r}-0.305^{* *} \\
(-0.04)\end{array}$ & $\begin{array}{r}-0.154^{*} \\
(-0.07)\end{array}$ & $\begin{array}{r}0.775^{* *} \\
(0.00)\end{array}$ & $\begin{array}{r}0.197^{* * *} \\
(0.00)\end{array}$ \\
\hline Observations & 6730 & 6306 & 6730 & 6730 \\
\hline
\end{tabular}

\section{Table 13. Cross-Section Regression of Changes in Social Indicators on Changes in} Tariffs, 2007-14

\begin{tabular}{|c|c|c|c|}
\hline & \multicolumn{3}{|c|}{$\begin{array}{c}\text { Dependent Variable: Change in Social Indicators by } \\
\text { District }\end{array}$} \\
\hline & $\begin{array}{c}\text { Headcount } \\
\text { Poverty Ratio }\end{array}$ & Poverty Gap & $\begin{array}{l}\text { Log expenditure } \\
\text { per person }\end{array}$ \\
\hline \multicolumn{4}{|l|}{ Not weighted by district observations } \\
\hline Change in District Tariffs (Imports-Weighted) & $\begin{array}{r}-1.319 * * * \\
(0.00)\end{array}$ & $\begin{array}{r}-1.160 * * * \\
(0.00)\end{array}$ & $\begin{array}{r}2.519^{* * *} \\
(0.00)\end{array}$ \\
\hline r2 & 0.020 & 0.050 & 0.037 \\
\hline Observations & 495 & 431 & 495 \\
\hline \multicolumn{4}{|l|}{ Weighted by district observations } \\
\hline Change in District Tariffs (Imports-Weighted) & $\begin{array}{r}-0.969 * * \\
(-0.01)\end{array}$ & $\begin{array}{r}-0.932 * * * \\
(0.00)\end{array}$ & $\begin{array}{r}2.315^{* * *} \\
(0.00)\end{array}$ \\
\hline $\mathrm{r} 2$ & 0.014 & 0.047 & 0.039 \\
\hline Observations & 495 & 431 & 495 \\
\hline
\end{tabular}

\section{CInternational Monetary Fund. Not for Redistribution}


The strength of the relation between tariffs and socioeconomic indicators at the district level a priori could indicate that there was no significant labor mobility or migration to allow producers to adjust to enhanced imports-competition. We could ideally analyze this by using data on outward migration so as to assess whether districts that faced higher reduction in their average tariffs also saw more outward migration that could have potentially alleviated the negative impact of liberalization. Unfortunately, there is no such data available.

However, Peru's household surveys do have information on the number of immigrants in each district that arrived within the last five years before 2014 and therefore we look at whether the change in this ratio was related at all to the changes in tariffs. The regression below shows that, as expected, reductions in expenditure per capita are related reductions in the immigration ratio, and that lower tariffs are also related to lower immigration to the district. The point estimate implies that a 10 percent reduction in tariffs is associated with a 5 percent lower ratio of immigrants.

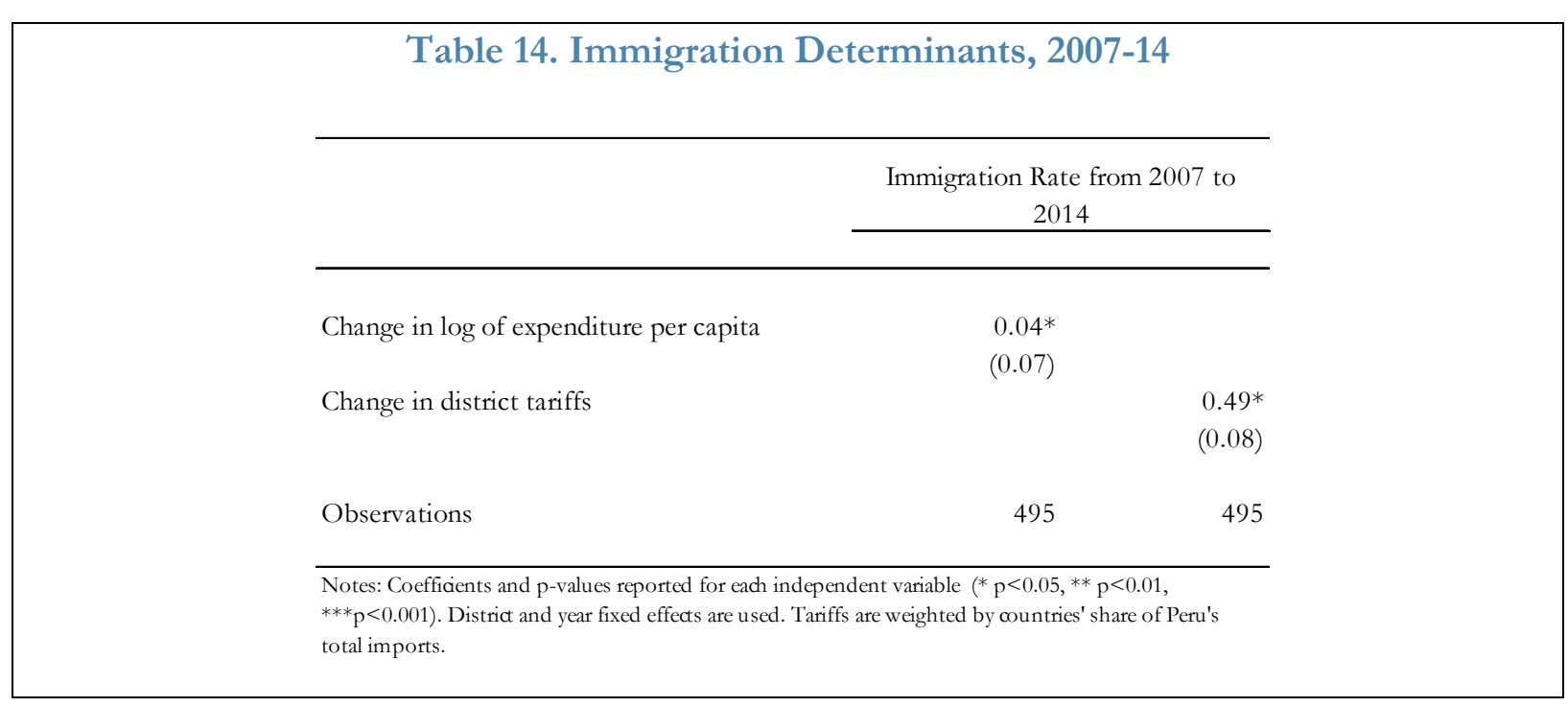

\section{Conclusion AND Policy IMPLiCATIONS}

Our analysis finds a significantly negative effect of tariff reductions through the imports competition channel despite no legal or cultural barriers to labor mobility in Peru, therefore supporting similar findings of the impact of higher trade integration in countries with high labor mobility (Autor and others, 2014; Kovak, 2013; and Dix-Carneiro and Kovak, 2016). Although there is no data to measure the impact of liberalization on outward migration, there is evidence that reductions in tariffs faced by district producers are associated with lower immigration rates, but this does not fully offset the negative impact on socioeconomic indicators.

The strength of these results in countries with high labor mobility underscores the need for policies to directly offset the impact of trade liberalization through the imports competition channel, especially on those that are economically vulnerable. Ideally, before any significant reduction in restrictions to imports, policy makers could estimate district level tariffs (as in equation 1) to identify those likely to be affected by liberalization through the imports competition channel. After such identification, they could protect and facilitate adjustment in likely to be affected districts by: (i) strengthening their social safety nets; (ii) financing (through 
vouchers) the retraining of their workers; (iii) implementing job search programs; and (iv) lowering costs of migration mainly by providing infrastructure (transport and telecommunications), as well as nationwide information that could ease migration (on jobs, housing). There is also a case for governments to set gradual/longer liberalization schedules for socially sensitive products. 


\section{REFERENCES}

Autor, David, David Dorn, and Gordon Hanson, 2013, "The China Syndrome: Local Labor Market Effects of Import Competition in the United States," American Economic Review, Vol. 103(6): 2121-68.

Beck, Thorsten, Asli Demirguc-Kunt, and Ross Levine, 2007, "Finance, Inequality and the Poor," Journal of Economic Growth, Vol. 12: 27-49.

Bown, Chad and Patricia Tovar, 2011, "Trade Liberalization, Antidumping, and Safeguards: Evidence from India's Tariff Reform,” Journal of Development Economics Vol. 96(1): 115-125.

Dix Carneiro, Rafael and Brian Kovak, 2016, "Trade Liberalization and Regional Dynamics," Bureau for Research and Economic Analysis of Development (BREAD) Working Paper No. 488.

Dollar, David and Art Kraay, 2001, “Trade, Growth and Poverty,” mimeo, Development Research Group, The World Bank.

Fajgelbaum, Pablo, Gene Grossman, and Elhanan Helpman, 2009, "Income Distribution, Product Quality, and International Trade,” NBER Working Paper No. 15329.

Goldberg, Pinelopi and Nina Pavcnik, 2004, "Trade, Inequality, and Poverty: What Do We Know? Evidence from Recent Trade Liberalization Episodes in Developing Countries," NBER Working Paper No. 10593.

Haltiwanger, John, 2011, "Globalization and Economic Volatility," in M. Bacchetta and M. Jansen (eds), Making Globalization Socially Sustainable, ILO and WTO, Geneva: 119-146.

Hassan, Rana, Devashish Mitra, Priya Ranjan, Reshad Ashan, 2012, "Trade liberalization and unemployment: Theory and evidence from India," Journal of Development Economics, Vol. 97: 269-280.

Krueger, Anne, 1983, Trade and Employment in Developing Countries: Volume 3: Synthesis and Conclusions, NBER, New York.

Kovak, Brian, 2013, "Regional Effects of Trade Reform: What Is the Correct Measure of Liberalization?," American Economic Review, Vol. 103 (5): 1960-76.

Le Goff, Maellan, and Raju Jan Singh, 2013, "Does Trade Reduce Poverty: A View from Africa," World Bank Policy Research Working Paper No. 6327.

McMillan, Margaret and Iñigo Verduzco, 2011, "New Evidence on Trade and Employment: An Overview," in Marion Jansen, Ralf Peters, José Manuel Salazar-Xirinachs (eds.), Trade and Employment: From Myths to Facts, International Labor Organization, Geneva: 23-60.

Newfarmer, Richard and Monika Sztajerowska, 2012, "Trade and Employment in a FastChanging World," in Douglas Lippoldt (ed.), Policy Priorities for International Trade and Jobs, pp. 7-73, OECD, Paris. 
Paz-Soldan, Julio, Maria del Carmen Rivera, and Gonzalo Salinas, 2000, "La Reforma Comercial y de Aduanas," in Abusada, Roberto, Fritz Du Bois, Eduardo Morón, and Jose Valderrama (eds), La Reforma Incompleta, Rescatando los Noventa, Instituto Peruano de Economía and Universidad del Pacífico, Lima.

Porto, Guido, 2003, “Trade Reforms, Market Access and Poverty in Argentina,” Policy Research Working Paper, No. 3135.

Sindzingre, Alice, 2005, "Explaining Threshold Effects of Globalization on Poverty: An Institutional Perspective," Research Paper, UNU-WIDER, United Nations University, No. $2005 / 53$.

Topalova, Petia, 2005, “Trade Liberalization, Poverty, and Inequality: Evidence from Indian Districts,” NBER Working Paper No. 11614.

Topalova, Petia, 2010, "Factor Immobility and Regional Impacts of Trade Liberalization: Evidence on Poverty from India," American Economic Journal: Applied Economics, Vol. 2 (4): $1-41$. 


\begin{tabular}{|c|c|c|c|c|}
\hline \multicolumn{5}{|c|}{$\begin{array}{l}\text { Annex Table } 1 . \\
\text { Peru's Imports by Source Country (2004-14, in \%) }\end{array}$} \\
\hline & 2004-15 & 2004-07 & $2008-11$ & 2012-14 \\
\hline United States & 20.0 & 20.7 & 19.5 & 20.0 \\
\hline China & 14.1 & 8.6 & 15.5 & 19.5 \\
\hline Brazil & 7.1 & 8.2 & 7.4 & 5.4 \\
\hline Ecuador & 5.3 & 6.0 & 5.1 & 4.5 \\
\hline Colombia & 4.5 & 5.5 & 4.2 & 3.3 \\
\hline Chile & 4.3 & 5.6 & 3.9 & 3.0 \\
\hline Argentina & 4.2 & 4.5 & 4.4 & 3.7 \\
\hline Mexico & 3.8 & 3.5 & 3.7 & 4.2 \\
\hline Others & 36.7 & 37.4 & 36.3 & 36.3 \\
\hline
\end{tabular}

